DOI: http://dx.doi.org/10.18203/2320-1770.ijrcog20161277

Review Article

\title{
Ideal antenatal care-does it exist?
}

\author{
Sanjay Singh*, Manash Biswas
}

Department of Obstetrics and Gynaecology, Armed Forces Medical College, Pune, Maharashtra, India

Received: 16 March 2016

Revised: 14 April 2016

Accepted: 14 April 2016

\section{*Correspondence:}

Dr. Sanjay Singh,

E-mail: drsanjaysingh@gmail.com

Copyright: ( ) the author(s), publisher and licensee Medip Academy. This is an open-access article distributed under the terms of the Creative Commons Attribution Non-Commercial License, which permits unrestricted non-commercial use, distribution, and reproduction in any medium, provided the original work is properly cited.

\begin{abstract}
Antenatal care is systematic supervision of a pregnant mother and its objective is to ensure a normal pregnancy with delivery of a healthy baby from a healthy mother. It is quite effective in reduction of maternal and perinatal mortality and morbidity. Varied antenatal care protocols exist in the literature and all aim towards the same goal. This review endeavours to find out a protocol that is ideal and that suits every pregnant woman, every institute and every country in the world. The review was carried out in the period of 1900-2015 by searching in pub med, embase, scopus, google scholar, web of sciences using relevant key words. Reports, articles, fact sheets and official publications of World health Organization (WHO), Ministry of health and family welfare-government of India and various other countries were also reviewed. The review suggests that no such ideal protocol appears to exist that suits the requirement of every pregnant woman / country. However, it is possible to make and implement a near ideal protocol which is evidence based and is logistically and economically viable, for an optimal pregnancy outcome.
\end{abstract}

Keywords: Antenatal care, Ideal antenatal care, Focused antenatal care, Traditional antenatal care, Maternal mortality, Antenatal screening

\section{INTRODUCTION}

Antenatal care is systematic supervision of a woman during pregnancy that involves history taking, examination and advice. In fact it starts before pregnancy (preconception counselling) and ends at delivery and post-partum period. Its objective is to ensure a normal pregnancy with delivery of a healthy baby from a healthy mother. Antenatal care plays a pivotal role in reduction of maternal mortality. The success story of reduction of maternal mortality in countries like Belarus, Sri Lanka, Maldives, Bhutan, Cambodia and Matlab etc certify this fact. $^{1,2,3}$ Various antenatal care protocols and guidelines exist in the literature and all aim towards the same goal. Too many protocols and guidelines at times create confusion and no single protocol meets the requirement of every pregnant woman in the world. This review endeavours to find out a protocol that is ideal and that suits every pregnant woman, every institute and every country in the world.
This review was carried out in the period of 1900-2015 by searching in Pub Med, Embase, Scopus, Google scholar, Web of sciences using different combinations of following terms - antenatal care, focussed antenatal care, traditional antenatal care, maternal mortality, perinatal mortality, antenatal screening, preconception screening, ideal antenatal care. Reports, articles, fact sheets, guidelines and various official publications of World health Organization (WHO), Ministry of health and family welfare-Govt of India and various other countries were also reviewed. Latest National Institute of Clinical Excellence (NICE) guidelines and American College of Obstetricians \& Gynecologists (ACOG) guidelines on antenatal care was also taken into account.

\section{Maternal mortality-current scenario}

Maternal mortality is considered as the mirror image of the quality of obstetric care. ${ }^{4,5}$ As per World Health Organization (WHO), there were 2,89,000 maternal 
deaths in the world in 2013. Out of this Sub-Saharan Africa region accounted for $62 \%$ of global deaths followed by Southern Asia at 24\%. 98\%-99\% of the maternal deaths occur in developing world and are mostly preventable. Amongst countries, India has the dubious distinction of having the highest estimated number of maternal deaths (17\%) followed by Nigeria (14\%).6 India is still far behind developed countries and even developing countries like Sri Lanka, Bangladesh and Pakistan. Although the maternal mortality ratio dropped from 212 deaths per 100,000 live births in 2007-09 to 178 in 2010-12, India is behind the target of 103 deaths per live births to be achieved by 2015 under the united nations-mandated Millennium Development Goals (MDGs).The MMR in southern states fell 17\% from 127 to 105 , closer to the MDGs. Assam and Uttar Pradesh/ Uttarakhand are the worst performing states, with an MMR of 328 and 292, respectively. Kerala and Tamilnadu have surpassed the MDG with an MMR of 66 and 90, respectively and have set an example for the other states to follow. ${ }^{7}$

\section{Causes of maternal deaths}

Approximately $70 \%$ of the maternal deaths are due to haemorrhage (25\%), sepsis (15\%), unsafe abortion (13\%), eclampsia (12\%), obstructed labour (8\%) and other direct causes (5-7\%). Indirect causes e.g. anaemia, cardiac disease, diabetes etc are responsible for about $20 \%$ of maternal deaths (Figure 1).

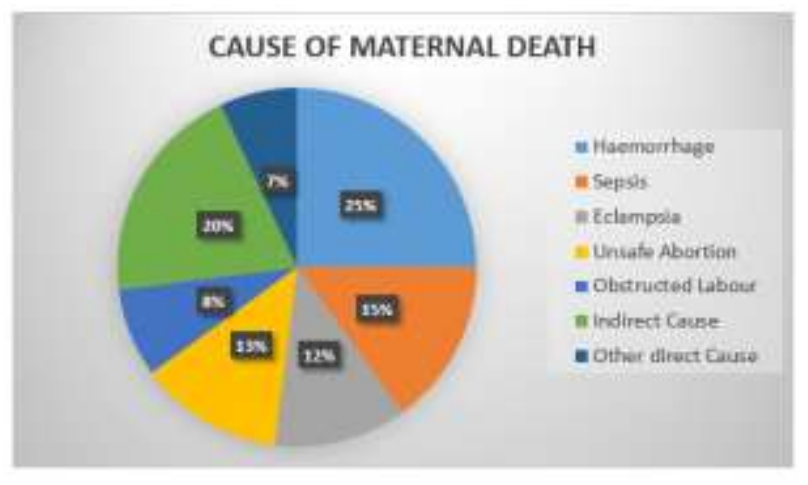

Figure 1: Causes of maternal deaths.

\section{Traditional antenatal care}

The history of antenatal care dates back to early $19^{\text {th }}$ century wherein the total concept of the antenatal care revolved around frequent antenatal visits and classifying pregnant women into low and high risk by predicting the complications ahead of time. However over a period of time several flaws were observed with this traditional system of antenatal care. For example frequent visits not necessarily mean improvement in quality of care and studies have shown that the more frequent antenatal visits do not improve pregnancy outcomes. ${ }^{8,9}$ Low risk cases may have a false sense of security as most of the complications of pregnancy e.g. obstructed labour; hypertensive disorders; antepartum and postpartum haemorrhage and post-partum infection etc are unpredictable and may occur late in pregnancy. $85 \%$ high risk cases may not develop complications at all and instead may have normal deliveries. Moreover, frequent visits mean cost and time, which logistically and financially may not be feasible for a service provider and the pregnant mother belonging to low socioeconomic strata of the society.

\section{Focused antenatal care (FANC)}

Villar et al conducted a multicenter randomized controlled trial with 25,000 women comparing routine prenatal care with an experimental model designed to minimize visits. They established the fact that no disadvantages were attributed to the regimen with fewer visits. $^{8}$ This novel concept of Focused antenatal care was adopted by World Health Organization (WHO) in 2002 and was implemented in sub-Saharan countries. ${ }^{10}$ Focused antenatal care is evidence based; goal directed and individualized woman centered antenatal care approach that emphasizes on quality of care. It addresses most prevalent health issues affecting women and new borns, adjusted for specific populations/regions and gestational age. FANC is the best approach for resourcelimited countries where health professionals are few and health infrastructures are limited. FANC is gaining much popularity because of its effectiveness in terms of reducing maternal and perinatal mortality and morbidity. ${ }^{9,10}$

\section{Components of focused antenatal care}

The goal of focused antenatal care is to promote maternal and newborn health and survival through:

A. Identification and surveillance of the pregnant woman and her expected child.

B. Recognition and management of pregnancy-related complications e.g. preeclampsia.

C. Recognition and treatment of underlying or concurrent illness.

D. Screening for conditions and diseases such as anaemia, STIs (particularly syphilis), HIV infection, mental health problems.

E. Preventive measures including tetanus toxoid immunisation, de-worming, iron and folic acid supplementation, intermittent preventive treatment of malaria in pregnancy (IPTp) and insecticide treated bed nets (ITN) in malaria endemic areas.

F. Advice and support to the woman and her family for developing healthy home behaviours for promotion of health.

G. Development of a birth and emergency preparedness plan that includes identification of the following elements: the desired place of birth; the preferred 
birth attendant; the location of the closest appropriate care facility; funds for birth-related and emergency expenses; a birth companion; support in looking after the home and children while the woman is away; transport to a health facility for the birth; transport in the case of an obstetric emergency; and identification of compatible blood donors in case of emergency.

H. Education of the pregnant mother and family members regarding danger signals of pregnancy e.g. vaginal bleeding, difficulty in breathing, fever, severe abdominal pain, severe headache/blurred vision, convulsions/loss of consciousness, labor pains before 37 weeks etc. in order to avoid delay in reporting for the management.

I. Promotion of post-partum family planning and birth spacing.

\section{Schedule of antenatal visits in focused antenatal care model}

Based on the existing risk factors on the first antenatal visit pregnant women are divided into two groups: basic component group and specialized component group. Those having no risk factor receive routine antenatal care and are included in the basic component group. Those who need special care based on their specific health conditions or risk factors, are included in the second group. Pre-set criteria are used to determine the eligibility of women to join the basic component. The pregnant woman belonging to basic component group may later on be included in the specialized care group if she in subsequent scheduled visit is found to have some complications/risk factor. In basic component group four antenatal visits are recommended: first between 8-12 weeks, second between 24-36 weeks, third at 32 weeks and forth between 36-38 weeks. In specialized care the visits are based on the specific health condition/risk factor (targeted and individualised care).The goals and activities of the four antenatal care model outlined in World Health Organization (WHO) clinical guidelines is appended in Table 1 and Table 2. ${ }^{10}$

\section{Ideal antenatal care}

Existing guidelines on antenatal care are not only based on specific health issues related to pregnancy but also on socioeconomic condition, demographic situation and prevalence of disease in a particular society, region or a country. Thus there exists no such ideal antenatal care protocol that meets the requirement of every individual, institution and a country. However it is possible to develop a tailor made prenatal care protocol based on basic principles and available evidences as discussed below which best suits the need of a pregnant woman.

\section{Frequency of visits}

As per National Institute of Clinical Excellence (NICE), $\mathrm{UK}$, for a woman who is nulliparous with an uncomplicated pregnancy, a schedule of 10 appointments should be adequate. For a woman who is parous with an uncomplicated pregnancy, a schedule of 7 appointments should be adequate. ${ }^{11}$ ACOG recommends traditional 14 antenatal visits. The WHO recommends a minimum of four antenatal visits for the countries with maternal mortality ratio above 300 per 100,000 live births, in order to provide basic antenatal care. However, FANC is the best approach for resource-limited countries where health professionals are few and health infrastructures are limited.

Table 1: Focused antenatal care (ANC): The four-visit ANC model outlined in WHO clinical Guidelines.

\begin{tabular}{|c|c|c|c|}
\hline \multicolumn{4}{|c|}{ Goals } \\
\hline $\begin{array}{l}\text { First Visit } \\
8-12 \text { weeks }\end{array}$ & $\begin{array}{l}\text { Second } \\
\text { Visit } \\
24-26 \\
\text { weeks }\end{array}$ & $\begin{array}{l}\text { Third Visit } \\
32 \text { weeks }\end{array}$ & $\begin{array}{l}\text { Fourth Visit } \\
36-38 \text { weeks }\end{array}$ \\
\hline $\begin{array}{l}\text { Confirm } \\
\text { pregnancy } \\
\text { and EDD }\end{array}$ & $\begin{array}{l}\text { 1. Assess } \\
\text { maternal \& } \\
\text { Foetal well } \\
\text { being }\end{array}$ & $\begin{array}{l}\text { 1. Assess } \\
\text { maternal \& } \\
\text { Foetal well } \\
\text { being }\end{array}$ & $\begin{array}{l}\text { 1. Assess } \\
\text { maternal \& } \\
\text { Foetal well being }\end{array}$ \\
\hline $\begin{array}{l}\text { Classify } \\
\text { woman for } \\
\text { basic ANC } \\
\text { (Four } \\
\text { Visits) or } \\
\text { more } \\
\text { specialized } \\
\text { care }\end{array}$ & $\begin{array}{l}\text { 2.Exclude } \\
\text { PIH \& } \\
\text { Anaemia }\end{array}$ & $\begin{array}{l}\text { 2.Exclude } \\
\text { PIH, } \\
\text { Anaemia, } \\
\text { Multiple } \\
\text { Pregnancy }\end{array}$ & $\begin{array}{l}\text { 2.Exclude PIH, } \\
\text { Anaemia, } \\
\text { Multiple } \\
\text { Pregnancy, } \\
\text { Malpresentation }\end{array}$ \\
\hline $\begin{array}{l}\text { Screen, } \\
\text { Treat, Give } \\
\text { preventive } \\
\text { measures }\end{array}$ & $\begin{array}{l}\text { 3. Give } \\
\text { preventive } \\
\text { measures }\end{array}$ & $\begin{array}{l}\text { 3. Give } \\
\text { preventive } \\
\text { measures }\end{array}$ & $\begin{array}{l}\text { 3. Give } \\
\text { preventive } \\
\text { measures }\end{array}$ \\
\hline $\begin{array}{l}\text { Develop a } \\
\text { birth and } \\
\text { emergency } \\
\text { plan }\end{array}$ & $\begin{array}{l}\text { 4. Review } \\
\& \text { modify } \\
\text { birth \& } \\
\text { emergency } \\
\text { plan }\end{array}$ & $\begin{array}{l}\text { 4. Review } \\
\& \text { modify } \\
\text { birth \& } \\
\text { emergency } \\
\text { plan }\end{array}$ & $\begin{array}{l}\text { 4. Review \& } \\
\text { modify birth \& } \\
\text { emergency plan }\end{array}$ \\
\hline $\begin{array}{l}\text { Advise \& } \\
\text { Counsel }\end{array}$ & $\begin{array}{l}\text { 5. Advise \& } \\
\text { Counsel }\end{array}$ & $\begin{array}{l}\text { 5. Advise \& } \\
\text { Counsel }\end{array}$ & $\begin{array}{l}\text { 5. Advise \& } \\
\text { Counsel }\end{array}$ \\
\hline
\end{tabular}

\section{Booking visit}

Most of the guidelines including NICE guidelines, recommend that booking visit should ideally be within the first trimester of pregnancy. Confirmation of pregnancy by urine pregnancy test or ultrasound scan is done. Detailed history, with an aim to assess risk factor, is an important component of booking visit. This includes menstrual history, obstetric history, medical and surgical history, family history and personal history. General examination includes measurement of height, weight, body mass index $(\mathrm{BMI})$, repeated weighing in cases of obesity and low BMI and measurement of baseline blood pressure. Cardiac examination should be done to rule out murmurs. NICE guideline does not suggest routine breast and pelvic examination. 
Table 2: Focused antenatal care (ANC): The four-visit ANC model outlined in WHO clinical Guidelines.

\begin{tabular}{|c|c|c|c|c|}
\hline Activities & $\begin{array}{l}\text { First visit (8-12 } \\
\text { weeks) }\end{array}$ & $\begin{array}{l}\text { Second visit (24-26 } \\
\text { weeks) }\end{array}$ & Third visit (32 weeks) & Fourth visit (36-38 weeks) \\
\hline $\begin{array}{l}\text { History } \\
\text { (ask, check } \\
\text { records) }\end{array}$ & $\begin{array}{l}\text { Assess significant } \\
\text { symptoms. Take } \\
\text { psychosocial, } \\
\text { medical and } \\
\text { obstetric history. } \\
\text { Confirm pregnancy } \\
\text { and calculate EDD. } \\
\text { Classify all women } \\
\text { (in some cases after } \\
\text { test results) }\end{array}$ & $\begin{array}{l}\text { Assess significant } \\
\text { symptoms. Check } \\
\text { record for previous } \\
\text { complications and } \\
\text { treatments during } \\
\text { the pregnancy. } \\
\text { Re-classification if } \\
\text { needed }\end{array}$ & $\begin{array}{l}\text { Assess significant } \\
\text { symptoms. Check } \\
\text { record for previous } \\
\text { complications and } \\
\text { treatments during } \\
\text { the pregnancy. } \\
\text { Re-classification if } \\
\text { needed }\end{array}$ & $\begin{array}{l}\text { Assess significant } \\
\text { symptoms. Check } \\
\text { record for previous } \\
\text { complications and } \\
\text { treatments during } \\
\text { the pregnancy. } \\
\text { Re-classification if } \\
\text { needed }\end{array}$ \\
\hline $\begin{array}{l}\text { Examination } \\
\text { (look, listen, feel) }\end{array}$ & $\begin{array}{l}\text { Complete general, } \\
\text { and } \\
\text { obstetrical } \\
\text { examination, BP }\end{array}$ & $\begin{array}{l}\text { Anaemia, BP, } \\
\text { fetal growth, and } \\
\text { movements }\end{array}$ & $\begin{array}{l}\text { Anaemia, BP, } \\
\text { fetal growth, multiple } \\
\text { pregnancy }\end{array}$ & $\begin{array}{l}\text { Anaemia, BP, fetal } \\
\text { growth and } \\
\text { movements, multiple } \\
\text { pregnancy, } \\
\text { malpresentation }\end{array}$ \\
\hline $\begin{array}{l}\text { Screening and } \\
\text { tests }\end{array}$ & $\begin{array}{l}\text { Haemoglobin } \\
\text { Syphilis, HIV } \\
\text { Proteinuria } \\
\text { Blood/Rh group* } \\
\text { Bacteriuria* }\end{array}$ & Bacteriuria* & Bacteriuria* & Bacteriuria* \\
\hline Treatments & $\begin{array}{l}\text { Syphilis } \\
\text { ARV if eligible } \\
\text { Treat bacteriuria if } \\
\text { indicated* }\end{array}$ & $\begin{array}{l}\text { Antihelminthic**, } \\
\text { ARV if eligible } \\
\text { Treat bacteriuria if } \\
\text { indicated* }\end{array}$ & $\begin{array}{l}\text { ARV if eligible } \\
\text { Treat bacteriuria if } \\
\text { indicated* }\end{array}$ & $\begin{array}{l}\text { ARV if eligible } \\
\text { If breech, ECV or } \\
\text { referral for ECV } \\
\text { Treat bacteriuria if } \\
\text { indicated* }\end{array}$ \\
\hline $\begin{array}{l}\text { Preventive } \\
\text { measures }\end{array}$ & $\begin{array}{l}\text { Tetanus toxoid } \\
\text { Iron and folate+ }\end{array}$ & $\begin{array}{l}\text { Tetanus toxoid, } \\
\text { Iron and folate } \\
\text { IPTp, ARV }\end{array}$ & $\begin{array}{l}\text { Iron and folate } \\
\text { IPTp } \\
\text { ARV }\end{array}$ & $\begin{array}{l}\text { Iron and folate } \\
\text { ARV }\end{array}$ \\
\hline $\begin{array}{l}\text { Health } \\
\text { education, } \\
\text { advice, and } \\
\text { counselling }\end{array}$ & $\begin{array}{l}\text { Self-care, alcohol } \\
\text { and } \\
\text { tobacco use, } \\
\text { nutrition, } \\
\text { safe sex, rest, } \\
\text { sleeping } \\
\text { under ITN, birth } \\
\text { and } \\
\text { emergency plan }\end{array}$ & $\begin{array}{l}\text { Birth and emergency } \\
\text { plan, reinforcement of } \\
\text { previous advice }\end{array}$ & $\begin{array}{l}\text { Birth and emergency plan, } \\
\text { infant feeding, } \\
\text { postpartum/postnatal care, } \\
\text { pregnancy } \\
\text { spacing, reinforcement } \\
\text { of previous advice }\end{array}$ & $\begin{array}{l}\text { Birth and emergency } \\
\text { plan, infant feeding, } \\
\text { postpartum/postnatal care, } \\
\text { pregnancy } \\
\text { spacing, reinforcement } \\
\text { of previous advice }\end{array}$ \\
\hline
\end{tabular}

\section{Screening lab tests}

Haemoglobin should be checked at booking visit and at 28 weeks. Blood grouping and $\mathrm{Rh}$ typing should be offered in early pregnancy and anti-D prophylaxis is offered to all non-sensitized $\mathrm{Rh}$ negative pregnant mothers at 28 weeks.

\section{Screening for infections}

Asymptomatic bacteriuria: The incidence of asymptomatic bacteruria is around $4-6 \% .25 \%$ of these women are likely to develop acute pyelonephritis, usually in third trimester, if left untreated. Treatment of asymptomatic bacteriuria reduces the risk of pyelonephritis and its associated complications like preterm labour and low birth weight infants. Thus screening for asymptomatic bacteruria ideally by mid stream urine culture is recommended.

Syphilis: Maternal syphilis can cause abortion, preterm labour, foetal death, foetal growth restriction, and neonatal infection. Any stage of maternal syphilis may result in foetal infection. So screening for syphilis should be offered at an early stage in antenatal care.

$H I V$ : Mother to child transmission at the time of delivery is the commonest cause of paediatric HIV infection. Approximately $15 \%$ to $40 \%$ of neonates born to nonbreast feeding, untreated, HIV infected mothers, get 
infected. Appropriate antenatal intervention reduce mother to child transmission significantly. In order to do so and to ensure medical personnel take adequate precautions, prenatal HIV screening using an opt-out approach is recommended.

Hepatitis B: $10 \%$ to $20 \%$ of $\mathrm{HBsAg}$ positive women transmit viral infection to their children. $90 \%$ of children infected during perinatal period develop chronic infection and up to $25 \%$ would develop chronic active hepatitis. Effective post natal intervention can be offered to infected women to decrease the risk of mother to child transmission.

Rubella: Rubella is one of the most complete teratogens, and sequelae of foetal infection are worst during organogenesis. Screening of rubella is recommended to identify women at risk of contracting rubella infection and to enable vaccination in the post natal period for the protection of future pregnancy.

Cervical infection with Chlamydia trachomatis and Neisseria gonorrhoea: The American Academy of Paediatrics and the American College of Obstetricians and Gynecologists (ACOG), 2012, recommend that screening for Chlamydia and Gonorrhoea should be offered to all women during first prenatal visit, with additional third trimester testing for those at increased risk. Risk factors include age younger than 25 years, unmarried status, recent change of sexual partner or multiple concurrent partners, history or presence of other sexually transmitted diseases and little or no prenatal care.

Group B streptococcal infection: The Centers for Disease Control and Prevention (2010B) and ACOG (2013b) recommends that vaginal and rectal group $B$ streptococcal (GBS) cultures be obtained in all women between 35-37 weeks gestation. Intrapartum antimicrobial prophylaxis is given to all whose cultures are positive.

The NICE guideline however does not recommend screening for Chlamydia and GBS infection. It also does not recommend screening for asymptomatic bacterial vaginosis, hepatitis $\mathrm{C}$, cytomegalo virus (CMV) and toxoplasma. As per Cochrane database treatment of asymptomatic bacterial vaginosis does not lower the risk of preterm birth and other adverse reproductive outcomes.

\section{Screening for clinical conditions}

Gestational Diabetes (GDM): NICE guidelines recommends risk based screening for GDM and suggests that screening for GDM using fasting blood sugar, random blood sugar, glucose challenge test and urinary sugar, should not be done. In our pretext, India is the diabetic capital of the world with 42 million diabetic cases. So universal screening for GDM is in order. Single screening test with $75 \mathrm{gm}, 2$ hours post sugar blood screening test, as per diabetes in pregnancy study group of India (DIPSI), appears to be economical and more convenient for the pregnant women. ${ }^{12}$

Preeclampsia: Eclampsia is an important cause of maternal mortality. Various biological, biochemical and biophysical markers implicated in the pathophysiology of preeclampsia, has been proposed to predict its development. None however has been found to be sensitive, reliable and economical. The NICE guideline thus recommends only blood pressure measurement and urinanalysis for protein to be carried out at each antenatal visit to screen for preeclampsia. ${ }^{13}$

Thalassemia and sickle cell aneamia: The incidence of thalassaemia and sickle cell aneamia is high in Southeast Asian countries including India. Thus screening for thalassaemia and sickle cell aneamia is recommended ideally by 10 weeks.

\section{Ultrasound scan}

NICE guide line recommend early ultrasounds scan between 10 weeks 0 days and 13 weeks 6 days to determine gestational age and to detect multiple pregnancies. CRL should be used to determine Gestational age. If CRL $>84 \mathrm{~mm}$, the gestational age should be assessed using HC. Ultrasound screening for foetal anomalies should be routinely offered, between 18 20. Foetal echocardiography involving the four chamber view of the foetal heart and outflow tract is recommended as part of routine anomaly scan.

\section{Screening for Down's syndrome}

Down's syndrome is an important cause of preventable mental retardation. As per NICE guideline and ACOG 2013c guideline all pregnant women should be offered screening for Down's syndrome. The combined test (nuchal translucency, beta-human chorionic gonadotrophin, pregnancy associated plasma protein-A) is offered to screen it between 11 weeks 0 days and 13 weeks 6 days. This is considered to be the best timing for the screening. However, for those who present late during pregnancy, triple (serum b-HCG, estradiol, $\alpha$-feto protein) or quadruple test (triple markers plus inhibin), should be offered between 15 weeks 0 days and 20 weeks 0 days.

The routine anomaly scan (at 18 weeks 0 days to 20 weeks 06 days) should not be used as Down's syndrome screening using soft markers. The presence of isolated soft markers, with the exception of nuchal fold, on routine anomaly scan should not be used to adjust the priori risk of Down's syndrome. The presence of an increased nuchal fold (6 millimetres or above) or two or more soft markers on the routine anomaly scan should prompt the offer of a referral to a foetal medicine specialist. 


\section{Preterm birth}

Routine screening for preterm birth is not recommended.

\section{Foetal growth and well being}

Symphysis-fundal height (SFH) should be recorded at each antenatal visit from 24 weeks onwards. Routine Doppler ultrasound should not be used in low risk pregnancies. SFH measurement should complement, rather than replace, palpation of pregnant uterus. ${ }^{14}$ Suspected foetal malpresentation should be confirmed by sonography. The Evidence does not support the routine use of antenatal electronic foetal heart rate monitoring and ultrasound scanning after 24 weeks of gestation for foetal wellbeing.

\section{Medications}

Folic Acid: Spina bifida and anencephaly account for $95 \%$ of the cases of neural tube defect. In up to $85 \%$ of the cases, this may be prevented by intake of folic acid four weeks prior and twelve weeks after the conception. The recommended dose of folic acid is 400ugm per day.

Vitamin D: Vit D deficiency is common during pregnancy. This is especially true in high risk group-such as women with limited sun exposure and black skin. Maternal Vit D deficiency cause congenital rickets, fracture in new born babies and disordered skeletal homeostasis. Thus all women are advised to take a Vit D supplement-10 ugm per day.

Iron: Routine iron supplementation with $60 \mathrm{mg}$ of elemental iron is recommended in all pregnant women.15However, further studies are needed to assess if this intervention results in a significant reduction in adverse maternal or infant outcomes. ${ }^{16}$

Vitamin A: Vit A supplementation is teratogenic therefore should be avoided during pregnancy.

Immunization during pregnancy: Immunization against tetanus not only protects the mother but also the neonates. The recommended schedule is two doses given 4-6 weeks apart. Women who are immunized in the past, a booster dose is sufficient. ${ }^{17}$ Following a fifteen year campaign, India has virtually eliminated maternal and neonatal tetanus. Maternal and neonatal tetanus is reduced to less than one case per thousand live births in all 675 districts of the country. WHO has validated this achievement.

\section{CONCLUSIONS}

Antenatal care reduces maternal mortality and morbidity and improves pregnancy outcome. No single antenatal care protocol meets the requirement of every pregnant woman, every institution or all the countries of the world.
However it is possible to make an ideal antenatal care protocol based on the health need of a pregnant woman, prevalence of the diseases and socioeconomic condition of the affected population in a particular country. Protocol thus made should be evidence based and logistically and economically viable for an optimal outcome.

Funding: No funding sources

Conflict of interest: None declared

Ethical approval: Not Required

\section{REFERENCES}

1. Deborah Maine, Murat Z. Akalin, Jyotsnamoy Chakraborty, Andres de Francisco and Michael Strong. Why Did Maternal Mortality Decline in Matlab? Studies in Family Planning.1996;27(4): 179-87.

2. Danel, Isabella. Maternal Mortality Reduction, Honduras, 1990-1997: A Case Study. Centers for Disease Control and Prevention. Report prepared for the World Bank.

3. Villar J, Báaqeel H, Piaggio G. WHO antenatal care randomised trial for the evaluation of a new model of routine antenatal care. Lancet. 2001;357:1551.

4. Herbst MA, Mercer BM, Beazley D, Meyer N, Carr T. Relationship of prenatal care and perinatal morbidity in LBW infants. Am J Obstet Gynecol. 2003; 189:930.

5. Vintzileos AM, Ananth CV, Smulian JC, Scorza WE, Knuppel RA. Prenatal care and black white foetal death disparity in the United States: heterogeneity of high risk conditions. Obstet Gynecol. 2002;99(3):483-9.

6. Trends in maternal mortality: 1990 to 2013.Estimates by WHO, UNICEF, UNFPA, the World Bank and United Nations Populations Division.

7. Special Bulletin on maternal Mortality in IndiaCensus of India. Available at www.censusindia.gov.in.

8. Villar J, Ba'aqeel $\mathrm{H}$, Piaggio $\mathrm{G}$, Lumbiganon $\mathrm{P}$, Belizán JM, Farnot U. WHO antenatal care randomised trial for the evaluation of a new model of routine antenatal care. Lancet. 2001;357(9268):155164.

9. Clement S, Candy B, Sikorski J, Wilson J, Smeeton $N$. Does reducing the frequency of routine antenatal visits have long term effects? Follow up of participants in a randomised controlled trial. $\mathrm{Br} \mathrm{J}$ Obstet Gynaecol. 1999;106(4):367-70.

10. Available at 200http://www.who.int/pmnch/media/publications/a onsectionIII_2.pdf.

11. NICE clinical guideline 62. Antenatal care. Issued March 2008. Accessed on December 2014. Available at www.guidance.nice.uk/cg62.

12. Balaji V, Balaji M, Anjalakshi C, Cynthia A, Arthi T, Seshiah V. Gestational diabetes mellitus in 
India.Journal of the association of Physicians of India. 2004;52:707-11.

13. Odibo AO, Rada CC, Cahill AG, Goetzinger KR, Tuuli MG, Odibo L, Macones GA, England SK. First trimester serum soluble fms-like tyrosine kinase-1, free VEGF, Placental growth factor and uterine artery doppler in Preeclampsia. J Perinatol. 2013 33(9):670 2013.

14. Buchamann E. Routine symphysis- fundal height measurement during pregnancy: RL commentary. The WHO Reproductive Health library;
Geneva:World Health Organization (Accessed on 20 February 2003).

15. International Nutritional Aneamia Consultative Group. Guidelines for the control of maternal nutritional anaemia. INACG,Washington, DC.1989.

16. Rosas JPP, Viteri FE. Effects of routine oral iron supplementation with or without folic acid for women during pregnancy. Cochrane database of Systematic reviews. 2007;4.

17. National Immunization schedule. Available at http://whoindia. Org/EN/Section284/Section 286.

Cite this article as: Singh S, Biswas M. Ideal antenatal care-does it exist? Int J Reprod Contracept Obstet Gynecol 2016;5:1285-91 